\title{
A NEW NP-UPLC METHOD FOR THE SEPARATION AND SIMULTANEOUS QUANTIFICATION OF RAMUCIRUMAB AND ERLOTINIB
}

\section{SIVA MADHU CHAITANYA ${ }^{*}$, SRINATH NISSANKARARAO ${ }^{2}$, SATYA LAKSHMI GANDHAM ${ }^{3}$}

${ }^{1}$ Department of Pharmaceutical Analysis, KJR College of Pharmacy, Burugupudi, Andhra Pradesh, India, ${ }^{2}$ New York City Metropolitan Area, Montvale, New Jersey, USA 07645, 3Department of Chemistry, Govt Degree College, Ganapavaram, Andhra Pradesh, India Email: chaitk31@gmail.com

Received: 02 Aug 2021, Revised and Accepted: 06 Sep 2021

\section{ABSTRACT}

Objective: This investigation demonstrates a stability-indicating and reliable "normal phase ultra-performance liquid chromatography" method to simultaneously quantify Ramucirumab and Erlotinib in the pharmaceutical dosage form.

Methods: Successful separation was accomplished using Chiralcel-OD-3 column (50 mm x $4.6 \mathrm{~mm}, 3 \mu \mathrm{m}$ ) with an isocratic type of elution using a mobile phase containing $n$-hexane+isopropyl alcohol+methanol $(89: 10: 1)$, respectively with $1.0 \mathrm{ml} / \mathrm{min}$ flow rate. The wavelength sensor was attuned at $266 \mathrm{~nm}$ to quantify Ramucirumab and Erlotinib.

Results: Erlotinib and Ramucirumab peaks were eluted with fine resolution at retention times 1.7807 min and 3.175 min, respectively. In the $10-150 \mu \mathrm{g} / \mathrm{ml}$ and $1-15 \mu \mathrm{g} / \mathrm{ml}$ concentration ranges for Erlotinib and Ramucirumab, the calibration graphs were linear, with regression coefficients of 0.99928 and 0.99976 , respectively. The suggested ultra-performance liquid chromatography approach has been shown as sensitive, precise, robust, accurate, specific and stability indicating through the resolution of Erlotinib and Ramucirumab from its degradationbased compounds.

Conclusion: The established ultra-performance liquid chromatography technique was effectively extended to the evaluation of Erlotinib and Ramucirumab in the pharmaceutical dosage form and the test results appeared satisfactory.

Keywords: Erlotinib, Ramucirumab, Development, Validation, NP-UPLC

(C) 2021 The Authors. Published by Innovare Academic Sciences Pvt Ltd. This is an open-access article under the CC BY license (https://creativecommons.org/licenses/by/4.0/) DOI: https://dx.doi.org/10.22159/ijap.2021v13i6.42815. Journal homepage: https://innovareacademics.in/journals/index.php/ijap

\section{INTRODUCTION}

Ramucirumab trade name Cyramza is a fully human monoclonal antibody [1, 2] (IgG1) developed for the treatment of solid tumors [3]. the US Food and Drug Administration (FDA) approved ramucirumab as a single-agent treatment for advanced gastric cancer [4,5] or gastroesophageal junction [6] (GEJ) adenocarcinoma [7] after prior treatment with fluoropyrimidine-or platinum-containing chemotherapy [8, 9]. The approval was based on the results of the REGARD trial, a phase III, international, randomized, double-blind, placebocontrolled study that evaluated the safety and efficacy of ramucirumab combinated with best supportive care versus placebo [10]. This trial has been criticised for its use of a placebo control arm, which does not reflect standard of care in most Western countries. Ramucirumab is a direct VEGFR2 antagonist [11], that binds with high affinity to the extracellular domain of VEGFR2 and blocks the binding of natural VEGFR ligands (VEGFA, VEGF-C and VEGF-D). These ligands are secreted by solid tumors to promote angiogenesis [12, 13] (formation of new blood vessels from pre-existing ones) and enhance tumor blood supply.
Binding of ramucirumab to VEGFR2 leads to inhibition of VEGFmediated tumor angiogenesis.

Erlotinib, sold under the brand name Tarceva among others, is a medication used to treat non-small cell lung cancer $[14,15]$ (NSCLC) and pancreatic cancer $[16,17]$. Specifically, it is used for NSCLC with mutations in the epidermal growth factor receptor $[18,19]$ (EGFR) either an exon 19 deletion (del19) or exon 21 (L858R) substitution mutation, which has spread to other parts of the body. It is taken by mouth. Common side effects include rash [20], diarrhea [21], muscle pain, joint pain, and cough [22]. Serious side effects may include lung problems, kidney problems [23], liver failure [24], gastrointestinal perforation [25], stroke, and corneal ulceration [26]. Use in pregnancy may harm the baby. It is a receptor tyrosine kinase inhibitor [27, 28], which acts on the epidermal growth factor receptor (EGFR). This paper proposes a novel sensitive stabilityindicating NP-UPLC procedure for the assessment of Erlotinib and Ramucirumab combination. The proposed process enables the rapid assessment of the Erlotinib and Ramucirumab in bulk drugs and formulation preparations without sample pretreatment with high precision and specificity and with no excipient intervention.

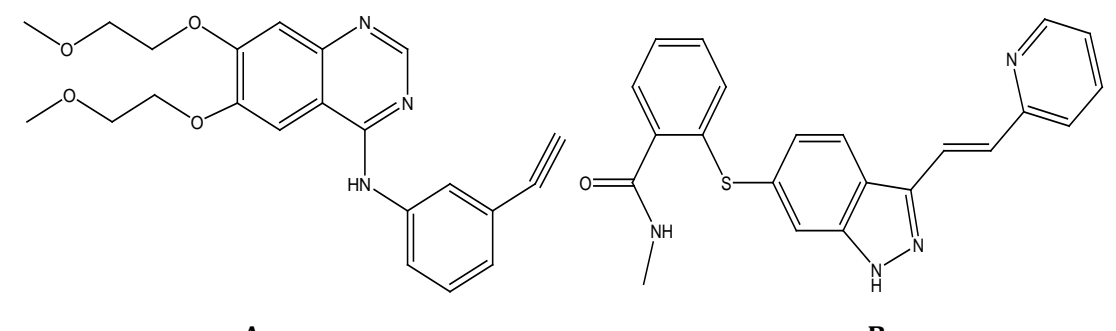

A

B

Fig. 1: Structure of (A) Erlotinib and (B) Ramucirumab 


\section{MATERIALS AND METHODS}

\section{Chemicals}

Acetonitrile, HPLC-grade methanol, water, isopropyl alcohol and $n$ hexane were purchased from Merck India Ltd, Mumbai, India. APIs of Erlotinib, Ramucirumab standards were procured from Glenmark, Mumbai. Ramucirumab injection formulation from Euphoria India Pharma with a lable claim of $10 \mathrm{mg} / \mathrm{ml}$ and Erlotinib tablet formulation from Modern Agencies with a lable claim of $100 \mathrm{mg}$ was used.

\section{The Instrumentation}

Waters Acquity UPLC with a quaternary pump, PDA detector with Empower 2.0 software was employed.

\section{Method optimization}

To optimize the chromatographic conditions, different ratios of phosphate buffer and the acetonitrile in the mobile phase with isocratic and gradient mode was tested. However, the mobile phase composition was modified at each trial to enhance the resolution and also to achieve acceptable retention times. Finally a mixture of n-hexane, isopropyl alcohol and methanol with isocractic elution was selected as mobile phase because it results in a greater response of active pharmacy ingredient. During the optimization of the method various stationary phases such as $\mathrm{C}_{8}, \mathrm{C}_{18}$ and amino, phenyl columns were tested. From these trials the peak shapes were relatively good with Chiralcel-OD-3 column of $50 \times 4.6 \mathrm{~mm}, 3 \mu$ with a PDA detector. The mobile phase flow rate has been done at $266 \mathrm{~nm}$ in order to obtain enough sensitivity. By using the above conditions we get retention times of Erlotinib and Ramucirumab were about $1.7 \mathrm{~min}$ and $3.1 \mathrm{~min}$ with a tailing factor of 1.18 and 1.26. The number of theoretical plates for Erlotinib and Ramucirumab were 7654, 9253 which indicate the column's successful output the \% RSD for six replicate injections was around $0.97 \%$ and $1.25 \%$, the proposed approach suggests that it is extremely precise. According to ICH guidelines, the method established was validated.

Till today there are no UPLC and HPLC methods were reported in the literature. Hence we developed method for the simultaneous quantification of Erlotinib and Ramucirumab. The developed UPLC method was utilized for the estimation of the combined drugs by in vitro method. Different extractions were tried using acetonitrile, methanol, and dimethylformamide.

\section{Validation procedure}

The analytical parameters such as system suitability, precision, specificity, accuracy, linearity, robustness, LOD, LOQ, forced degradation and stability were validated according to ICH Q2 (R1) guidelines $[29,30]$.

\section{Preparation of buffer}

Add $89 \mathrm{ml}$ of $\mathrm{n}$-hexane and $10 \mathrm{ml}$ of isopropyl alcohol and $1 \mathrm{ml}$ of methanol and filter through $0.45 \mu$ filter paper.

\section{Chromatographic conditions}

The UPLC analysis was performed on a normal phase UPLC system with isocratic elution mode using a mobile phase of n-hexane, isopropyl alcohol and methanol (89:10:1) and Chiralcel-OD-3 (50x4.6 mm, $3 \mu$ ) column with a flow rate of $1 \mathrm{ml} / \mathrm{min}$.

\section{Diluent}

Mobile phase was used as a diluent.

\section{Preparation of the standard solution}

Standard Erlotinib and Ramucirumab solution containing $100 \mu \mathrm{g} / \mathrm{ml}$ and $10 \mu \mathrm{g} / \mathrm{ml}$ was prepared by dissolving $100 \mathrm{mg}$ of Erlotinib and 10 $\mathrm{mg}$ of Ramucirumab in $100 \mathrm{ml}$ of mobile phase solvent blend. The standard Erlotinib and Ramucirumab solution were diluted employing mobile phase solvent blend further as needed.

\section{Preparation of the sample solution}

Sample Erlotinib and Ramucirumab solution containing $100 \mu \mathrm{g} / \mathrm{ml}$ and $10 \mu \mathrm{g} / \mathrm{ml}$ was prepared by dissolving $154 \mathrm{mg}$ of Erlotinib sample (lable claim $100 \mathrm{mg}$ ) and $10 \mathrm{mg}$ of Ramucirumab (lable claim $10 \mathrm{mg} / \mathrm{ml}$ ) in $100 \mathrm{ml}$ of mobile phase solvent blend. The standard Erlotinib and Ramucirumab solution were diluted employing mobile phase solvent blend further as needed.

\section{RESULTS AND DISCUSSION}

In acquiescence with ICH recommendations, the validity parameters were established [31].

\section{System suitability}

In System suitability injecting standard solution and reported USP tailing and plate count values are tabulated in table 1.

Table 1: Results of system suitability

\begin{tabular}{llll}
\hline System suitability parameter & Acceptance criteria & Drug name \\
\cline { 3 - 4 } & & Erlotinib & Ramucirumab \\
\hline USP Plate Count & NLT 2000 & 7654 & 9253 \\
USP Tailing & NMT 2.0 & 1.18 & 1.26 \\
USP Resolution & NLT 2.0 & - & 8.42 \\
\% RSD & NMT 2.0 & 0.97 & 1.25 \\
\hline
\end{tabular}

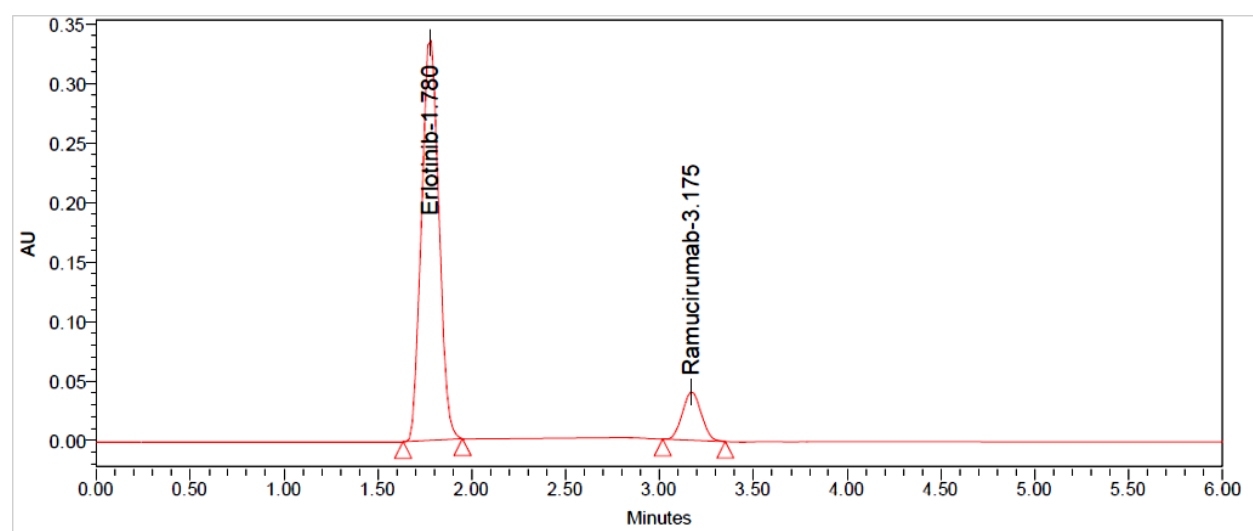

Fig. 2: Chromatogram of standard 


\section{Specificity}

In this test method placebo, standard and sample solutions were analyzed individually to examine the interference. The below fig. shows that the active ingredients were well separated from blank and their excipients and there was no interference of placebo with the principal peak. Hence the method is specific.

\section{Linearity}

During this work, the linearity of area response was checked for both Erlotinib and Ramucirumab. Chromatographed solutions with concentrations of $10-150 \mu \mathrm{g} / \mathrm{ml}$ for Erlotinib and $1-15 \mu \mathrm{g} / \mathrm{ml}$ for
Ramucirumab given linear peak response areas. The regression line equation, regression coefficient and Erlotinib and Ramucirumab calibration curves are shown in fig. 4 .

\section{Accuracy}

The accuracy was determined by assay of Erlotinib and Ramucirumab in spiked Erlotinib and Ramucirumab samples according to the proposed method. Three diverse quantities (50\% quantity degree, $100 \%$ quantity degree and $150 \%$ quantity degree) of Erlotinib and Ramucirumab standards were put into samples. The results are given in table 3 .

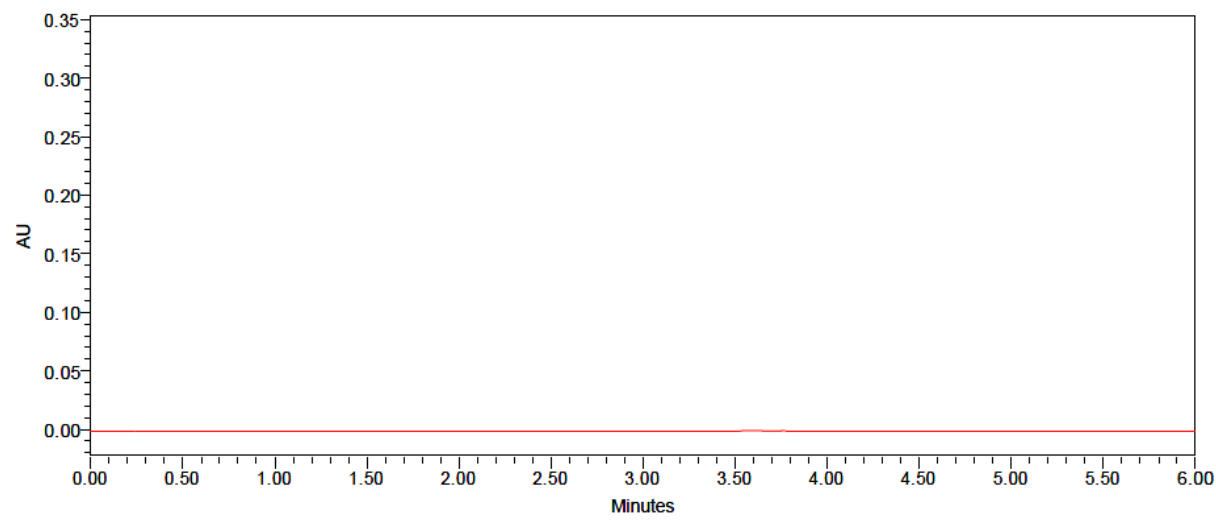

Fig. 3: Chromatogram of blank

Table 2: Linearity of erlotinib and ramucirumab

\begin{tabular}{|c|c|c|c|c|}
\hline S. No. & Conc $\mu \mathrm{g} / \mathrm{ml}$ & Erlotinib area count & Conc. $\mu \mathrm{g} / \mathrm{ml}$ & Ramucirumab area count \\
\hline 1 & 10.00 & 241110 & 1.00 & 36383 \\
\hline 2 & 25.00 & 514159 & 2.50 & 74638 \\
\hline 3 & 50.00 & 1097769 & 5.00 & 146882 \\
\hline 4 & 100.00 & 2158351 & 10.00 & 280360 \\
\hline 5 & 125.00 & 2622646 & 12.50 & 350920 \\
\hline 6 & 150.00 & 3051942 & 15.00 & 427679 \\
\hline Correl coef & & 0.99928 & & 0.99976 \\
\hline Slope & & 20600.10 & & 27976.37 \\
\hline intercept & & 29989.91 & & 4278.44 \\
\hline
\end{tabular}

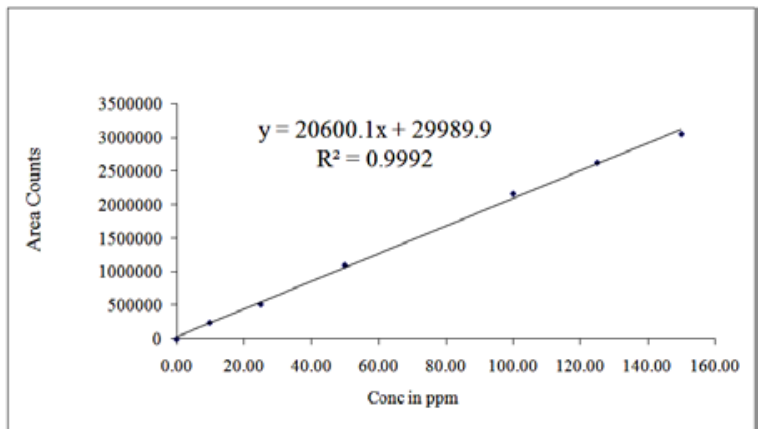

Erlotinib

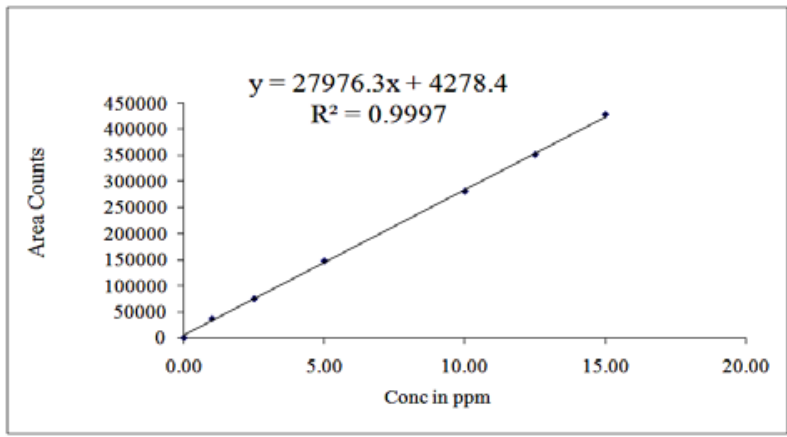

Ramucirumab

Fig. 4: Calibration plots of (A) Erlotinib (B) Ramucirumab

Table 3: Results of accuracy

\begin{tabular}{llll}
\hline S. No. & \% Level & Erlotinib \% recovery & Ramucirumab \% recovery \\
\hline 1 & 50 & 99.24 & 99.66 \\
2 & 100 & 100.36 & 99.87 \\
3 & 150 & 100.48 & 99.99 \\
mean & & 100.03 & 99.84 \\
SD & & 0.684 & 0.167 \\
\hline
\end{tabular}

mean $+\mathrm{SD}(\mathrm{n}=3)$ 


\section{Precision}

The precision measurements were assessed using measurements of Erlotinib and Ramucirumab solution $(100 \mu \mathrm{g} / \mathrm{ml}$ and $10 \mu \mathrm{g} / \mathrm{ml})$ repeated six times within the day. The precision was validated by the RSD measurements of the Erlotinib and Ramucirumab peak areas, while the accuracy was validated by the Erlotinib and Ramucirumab percentage content assays. These results are given below table 4 .

\section{Intraday precision}

Six replicates of a standard solution containing Erlotinib $(100 \mu \mathrm{g} / \mathrm{ml})$ and Ramucirumab $(10 \mu \mathrm{g} / \mathrm{ml})$ were analysed on the same day. Peak areas were calculated, which were used to calculate mean, SD and $\%$ RSD values.

\section{Intermediate precision}

Six replicates of the standard solution were studied by various researchers, and on separate days different instruments were tested. The peak regions used to determine mean percent RSD values have been calculated. The results are given in the following table.

\section{Inter-day precision}

Six replicates of a sample solution containing Erlotinib $(100 \mu \mathrm{g} / \mathrm{ml})$ and Ramucirumab $(10 \mu \mathrm{g} / \mathrm{ml})$ were analysed on a different day. Peak areas were calculated which were used to calculate mean, SD and $\%$ RSD values. The present method was found to be precise as the RSD values were less than $2 \%$ and also the percentage assay values were close to be $100 \%$. The results are given in table 5 .

Table 4: Intraday precision results of erlotinib and ramucirumab

\begin{tabular}{|c|c|c|c|c|c|c|}
\hline \multicolumn{4}{|c|}{ Erlotinib } & \multicolumn{3}{|l|}{ Ramucirumab } \\
\hline S. No. & Conc. $(\mu \mathrm{g} / \mathrm{ml})$ & Area counts & $\%$ assay as is & Conc. $(\mu \mathrm{g} / \mathrm{ml})$ & Area counts & $\%$ assay as is \\
\hline 1 & & 2154632 & 100.55 & & 284567 & 100.32 \\
\hline 2 & 100 & 2174583 & 101.24 & 10 & 283512 & 99.46 \\
\hline 3 & & 2153262 & 100.36 & & 284531 & 100.33 \\
\hline 4 & & 2146398 & 100.17 & & 281574 & 100.18 \\
\hline 5 & & 2147589 & 99.98 & & 284453 & 100.21 \\
\hline 6 & & 2163215 & 99.67 & & 285201 & 100.09 \\
\hline$\%$ RSD & 0.494 & & & 0.456 & & \\
\hline mean & 100.33 & & & 100.10 & & \\
\hline SD & 0.539 & & & 0.325 & & \\
\hline
\end{tabular}

mean $+\mathrm{SD}(\mathrm{n}=6)$

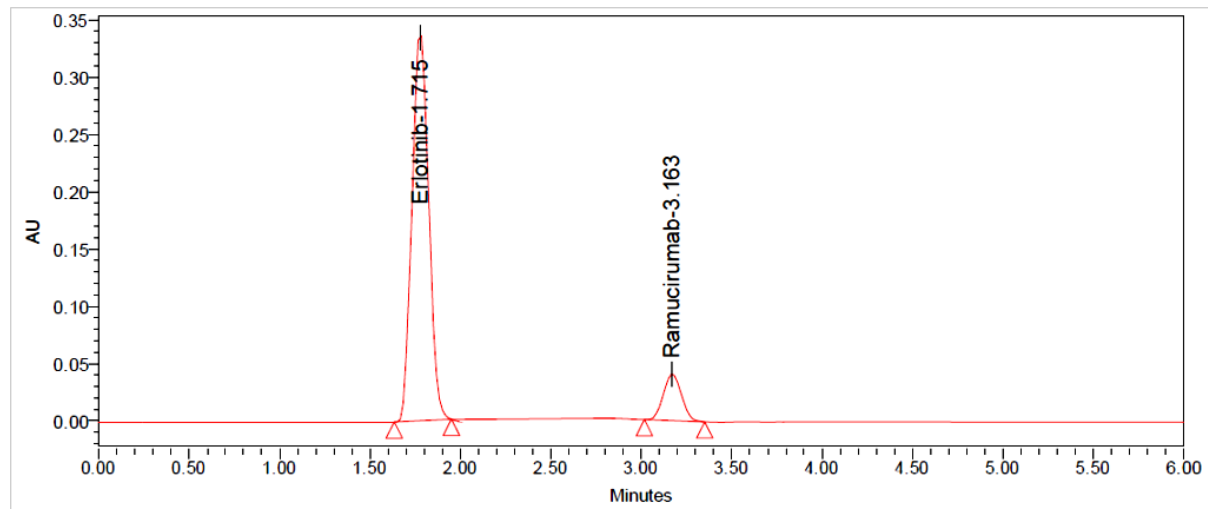

Fig. 5: Chromatogram of method precision

Table 5: Inter-day outcomes of accuracy of Erlotinib and Ramucirumab

\begin{tabular}{|c|c|c|c|c|c|c|}
\hline \multicolumn{4}{|c|}{ Erlotinib } & \multicolumn{3}{|l|}{ Ramucirumab } \\
\hline S. No. & Conc. $(\mu \mathrm{g} / \mathrm{ml})$ & Area counts & \% assay as is & Conc. $(\mu \mathrm{g} / \mathrm{ml})$ & Area count & $\%$ assay as is \\
\hline 1 & & 2142301 & 100.22 & 10 & 285649 & 100.24 \\
\hline 2 & 175 & 2129586 & 100.14 & & 284732 & 98.34 \\
\hline 3 & & 2137458 & 100.36 & & 289645 & 99.17 \\
\hline 4 & & 2146953 & 101.41 & & 283541 & 98.52 \\
\hline 5 & & 2103569 & 100.08 & & 282754 & 99.33 \\
\hline 6 & & 2121593 & 99.88 & & 289362 & 99.94 \\
\hline$\%$ RSD & 0.746 & & & 1.024 & & \\
\hline Mean & 100.35 & & & 99.26 & & \\
\hline SD & 0.544 & & & 0.752 & & \\
\hline
\end{tabular}

mean+SD $(n=6)$

Table 6: LOD and LOQ for erlotinib and ramucirumab

\begin{tabular}{|c|c|c|c|c|c|c|c|}
\hline \multicolumn{4}{|l|}{ Erlotinib } & \multicolumn{4}{|l|}{ Ramucirumab } \\
\hline LOD & & LOQ & & LOD & & LOQ & \\
\hline Concentration & $\mathrm{s} / \mathrm{n}$ & Concentration & $\mathrm{s} / \mathrm{n}$ & concentration & $\mathrm{s} / \mathrm{n}$ & Concentration & $\mathrm{s} / \mathrm{n}$ \\
\hline $0.125 \mu \mathrm{g} / \mathrm{ml}$ & 8 & $0.413 \mu \mathrm{g} / \mathrm{ml}$ & 27 & $0.013 \mu \mathrm{g} / \mathrm{ml}$ & 4 & $0.041 \mu \mathrm{g} / \mathrm{ml}$ & 24 \\
\hline
\end{tabular}




\section{LOD and LOQ}

Both LOD and LOQ were measured utilizing a signal-to-noise methodology. LOQ and LOD were defined as the Erlotinib and Ramucirumab concentration levels that ensuing a peak height of 10 times and 3 times, respectively, the baseline noise.

\section{Robustness}

The robustness was measured using peak area measurements of Erlotinib and Ramucirumab solution $(100 \mu \mathrm{g} / \mathrm{ml}$ and $10 \mu \mathrm{g} / \mathrm{ml})$ with considerably changed parameters in UPLC assay operating conditions. The changed parameters and peak areas obtained were presented in table 7 .

\section{Stability}

The sample solution was kept at room temperature and at $2-8{ }^{\circ} \mathrm{C}$ up to $24 \mathrm{~h}$. Then these solutions were pumped into the device and calculate the $\%$ of deviation from initial to $24 \mathrm{~h}$ [32]. There was no significant deviation observed and confirmed that the solutions were stable up to $24 \mathrm{~h}$ percentage of the assay was not quite $2 \%$. There is no effect in storage conditions for Erlotinib and Ramucirumab drugs. The results are given below table 8 .

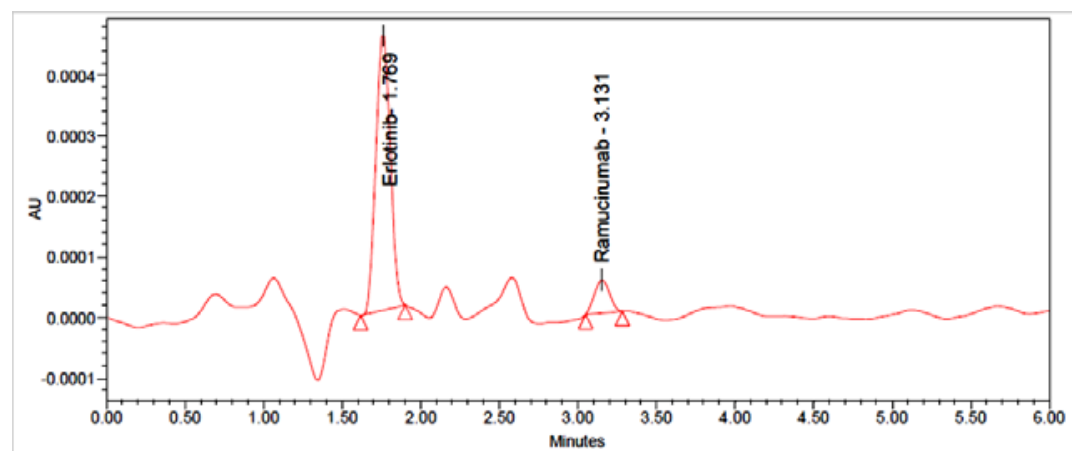

A

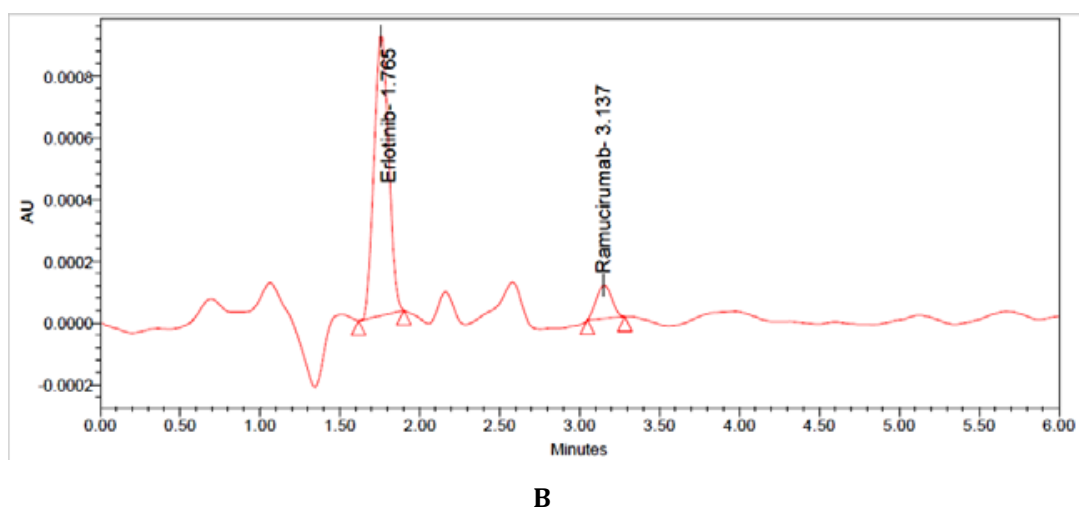

Fig. 6: Chromatogram of (A) LOD and (B) LOQ

Table 7: Robustness data of Erlotinib and Ramucirumab

\begin{tabular}{lll}
\hline Parameter name & \% RSD & Ramucirumab \\
\cline { 2 - 3 } & Erlotinib & 0.66 \\
\hline Flow minus $(0.8 \mathrm{ml} / \mathrm{min}$ & 0.52 & 0.49 \\
Flow plus $(1.2 \mathrm{ml} / \mathrm{min})$ & 0.69 & 0.99 \\
Organic minus $(-10 \%)$ & 1.42 & 0.47 \\
Organic plus (+10\%) & 0.71 & \\
\hline
\end{tabular}

Table 8: Stability results of Erlotinib and Ramucirumab

\begin{tabular}{|c|c|c|c|c|}
\hline \multirow[t]{2}{*}{ Stability } & \multicolumn{2}{|c|}{ Erlotinib } & \multicolumn{2}{|c|}{ Ramucirumab } \\
\hline & Purity & \% of deviation & Purity & $\%$ of deviation \\
\hline Initial & 100.1 & 0.00 & 99.9 & 0.00 \\
\hline $6 \mathrm{H}$ & 99.5 & -0.60 & 99.7 & -0.20 \\
\hline $12 \mathrm{H}$ & 99 & -1.10 & 99.6 & -0.30 \\
\hline $18 \mathrm{H}$ & 98.5 & -1.60 & 98.9 & -1.00 \\
\hline $24 \mathrm{H}$ & 98.2 & -1.90 & 98.4 & -1.50 \\
\hline
\end{tabular}

\section{Degradation studies}

The Erlotinib and Ramucirumab standard was subjected into various forced degradation conditions to effect partial degradation of the drug. Studies of forced degradation have carried out to find out that the method is suitable for products of degradation [33, 34]. In addition, the studies provide details about the conditions during which the drug is unstable, in order that the measures are often taken during formulation to avoid potential instabilities [35].

\section{Acid degradation}

Acid degradation was done by using $1 \mathrm{~N} \mathrm{HCl}$ and $14.2 \%$ of Erlotinib and $15.8 \%$ of Ramucirumab degradation was observed. 


\section{Alkali degradation}

Alkali degradation was done at $1 \mathrm{~N} \mathrm{NaOH}$ and $16.2 \%$ of Erlotinib and $15.1 \%$ of Ramucirumab degradation was observed.

\section{Peroxide degradation}

Peroxide degradation was performed with 30\% hydrogen peroxide and $14.9 \%$ Erlotinib, $15.5 \%$ of Ramucirumab degradation was observed.

\section{Reduction degradation}

Reduction degradation was performed with $30 \%$ sodium bi sulphate solution, $15.9 \%$ Erlotinib and 14.4\% Ramucirumab degradation was observed.

\section{Thermal degradation}

In thermal degradation, the standard was degraded to $15.6 \%$ of Erlotinib and $13.7 \%$ of Ramucirumab.

\section{Hydrolysis degradation}

In hydrolysis degradation the standard was degraded to $12.7 \%$ of Erlotinib and $12.0 \%$ of Ramucirumab.

All degradation results are tabulated in table 9.

\section{CONCLUSION}

An Ultra-performance liquid chromatography process for determining the combination of Erlotinib and Ramucirumab in individual formulation form and pure form has been described in the established method. The present Ultra-performance liquid chromatography process is exemplified by its speed, ease and relatively inexpensive. The successful validity criteria of the proposed approach permit its use in laboratories for quality control.

Table 9: Forced degradation results of Erlotinib and Ramucirumab

\begin{tabular}{llll}
\hline Degradation condition & Erlotinib & Ramucirumab & \% assay \\
\cline { 2 - 4 } & \% assay & \%Deg & 84.3 \\
\hline Acid degradation & 85.9 & 14.2 & 15.8 \\
Alkali degradation & 83.8 & 16.2 & 84.9 \\
Peroxide degradation & 85.1 & 14.9 & 85.6 \\
Reduction degradation & 84.1 & 15.9 & 86.3 \\
Thermal degradation & 84.4 & 15.6 & 85.2 \\
Hydrolysis degradation & 87.3 & 12.7 & 14.4 \\
\hline
\end{tabular}

\section{ACKNOWLEDGEMENT}

The authors are thankful to Shree Icon Pharmaceutical Laboratories to complete this research work.

\section{FUNDING}

Nil

\section{AUTHORS CONTRIBUTIONS}

All authors have contributed equally.

\section{CONFLICTS OF INTERESTS}

Declared none

\section{REFERENCES}

1. Ho M, Feng M, Fisher RJ, Rader C, Pastan I. A novel high-affinity human monoclonal antibody to mesothelin. Int J Cancer. 2011;128(9):2020-30. doi: 10.1002/ijc.25557, PMID 20635390

2. Siegel DL. Recombinant monoclonal antibody technology. Transfus Clin Biol. 2002 Jan;9(1):15-22. doi: 10.1016/s1246-7820(01)00210-5, PMID 11889896.

3. Ambrosi D, Mollica F. On the mechanics of a growing tumor. Int J Eng Sci.2002;40(12):1297-316. doi: 10.1016/S00207225(02)00014-9.

4. Amal H, Leja M, Funka K, Skapars R, Sivins A, Ancans G, Liepniece-Karele I, Kikuste I, Lasina I, Haick H. Detection of precancerous gastric lesions and gastric cancer through exhaled breath. Gut. 2016;65(3):400-7. doi: 10.1136/gutjnl2014-308536, PMID 25869737.

5. Qin J, Liu M, Ding Q, Ji X, Hao Y, Wu X, Xiong J. The direct effect of estrogen on cell viability and apoptosis in human gastric cancer cells. Mol Cell Biochem. 2014;395(1-2):99-107. doi: 10.1007/s11010-014-2115-2, PMID 24934239.

6. Lenglinger J, See SF, Beller L, Cosentini E, Asari R, Wrba F, Riegler M, Schoppmann SF. The cardia: esophageal or gastric? Critical reviewing the anatomy and histopathology of the esophagogastric junction. Acta Chir Iugosl. 2012;59(3):15-26. doi: 10.2298/aci1203015l, PMID 23654002.

7. Bond-Smith G, Banga N, Hammond TM, Imber CJ. Pancreatic adenocarcinoma. BMJ (clinical research Ed.). 2012;344:e2476.

8. Alfarouk KO, Stock CM, Taylor S, Walsh M, Muddathir AK Verduzco D, Bashir AH, Mohammed OY, Elhassan GO,
Harguindey S, Reshkin SJ, Ibrahim ME, Rauch C. Resistance to cancer chemotherapy: failure in drug response from ADME to P-gp. Cancer Cell Int. 2015;15:71. doi: 10.1186/s12935-0150221-1, PMID 26180516.

9. Goldman B. Multidrug resistance: can new drugs help chemotherapy score against cancer? J Natl Cancer Inst. 2003;95(4):255-7. doi: 10.1093/jnci/95.4.255, PMID 12591977.

10. Fuchs CS, Tomasek J, Yong CJ, Dumitru F, Passalacqua R, Goswami C, Safran H, Dos Santos LV, Aprile G, Ferry DR, Melichar B, Tehfe M, Topuzov E, Zalcberg JR, Chau I, Campbell W, Sivanandan C, Pikiel J, Koshiji M, Hsu Y, Liepa AM, Gao L, Schwartz JD, Tabernero J, REGARD Trial Investigators. Ramucirumab monotherapy for previously treated advanced gastric or gastro-oesophageal junction adenocarcinoma (REGARD): an international, randomised, multicentre, placebocontrolled, phase 3 trial. Lancet. 2014;383(9911):31-9. doi: 10.1016/S0140-6736(13)61719-5, PMID 24094768.

11. Glubb DM, Cerri E, Giese A, Zhang W, Mirza O, Thompson EE, Chen P, Das S, Jassem J, Rzyman W, Lingen MW, Salgia R, Hirsch FR, Dziadziuszko R, Ballmer-Hofer K, Innocenti F. Novel functional germline variants in the VEGF receptor 2 gene and their effect on gene expression and microvessel density in lung cancer. Clin Cancer Res. 2011;17(16):5257-67. doi: 10.1158/1078-0432.CCR-11-0379, PMID 21712447.

12. Birbrair A, Zhang T, Wang ZM, Messi ML, Olson JD, Mintz A, Delbono 0. Type-2 pericytes participate in normal and tumoral angiogenesis. Am J Physiol Cell Physiol. 2014;307(1):C25-38. doi: 10.1152/ajpcell.00084.2014, PMID 24788248.

13. Lee D, Kim D, Choi YB, Kang K, Sung ES, Ahn JH, Goo J, Yeom DH Jang HS, Moon KD, Lee SH, You WK. Simultaneous blockade of VEGF and Dll4 by HD105, a bispecific antibody, inhibits tumor progression and angiogenesis. mAbs. 2016;8(5):892-904. doi: 10.1080/19420862.2016.1171432, PMID 27049350.

14. Simon GR, Turrisi A, American College of Chest Physicians Management of small-cell lung cancer: ACCP evidence-based clinical practice guidelines (2nd edition). Chest. 2nd ed. 2007;132(3); Suppl:324S-39S. doi: 10.1378/chest.07-1385, PMID 17873178.

15. Yang ZY, Liu L, Mao C, Wu XY, Huang YF, Hu XF, Tang JL. Chemotherapy with cetuximab versus chemotherapy alone for chemotherapy-naive advanced non-small cell lung cancer. Cochrane Database Syst Rev. 2014;(11):CD009948. doi: 10.1002/14651858.CD009948.pub2, PMID 25400254. 
16. US Preventive Services Task Force, Owens DK, Davidson KW Krist AH, Barry MJ, Cabana M, Caughey AB, Curry SJ, Doubeni CA Epling JW, Kubik M, Landefeld CS, Mangione CM, Pbert L, Silverstein M, Simon MA, Tseng CW, Wong JB. Screening for pancreatic cancer: US Preventive Services Task Force reaffirmation recommendation statement. JAMA. 2019;322(5):438-44. doi: 10.1001/jama.2019.10232, PMID 31386141

17. Rossi ML, Rehman AA, Gondi CS. Therapeutic options for the management of pancreatic cancer. World J Gastroenterol. 2014;20(32):11142-59. 10.3748/wjg.v20.i32.11142, PMID 25170201.

18. Bonaccorsi L, Muratori M, Carloni V, Marchiani S, Formigli L, Forti G, Baldi E. The androgen receptor associates with the epidermal growth factor receptor in androgen-sensitive prostate cancer cells. Steroids. 2004;69(8-9):549-52. doi: 10.1016/j.steroids.2004.05.011, PMID 15288768.

19. Kim SW, Hayashi M, Lo JF, Yang Y, Yoo JS, Lee JD. ADPribosylation factor 4 small GTPase mediates epidermal growth factor receptor-dependent phospholipase D2 activation. J Biol Chem. 2003;278(4):2661-8. doi: 10.1074/jbc.M205819200 PMID 12446727.

20. Boyd MA, Menon P, Graves S, Gordon DL. A febrile illness with generalized papular rash involving the palms and soles. Clin Infect Dis. 2007;44(5):704, 755-6. doi: 10.1086/511637, PMID 17278064.

21. DuPont HL. Acute infectious diarrhea in immunocompetent adults. N Engl J Med.2014;370(16):1532-40. doi: 10.1056/NEJMra1301069, PMID 24738670.

22. Pavord ID, Chung KF. Management of chronic cough. Lancet. 2008;371(9621):1375-84. doi: 10.1016/S01406736(08)60596-6, PMID 18424326.

23. Liao M, Sung C, Hung K, Wu C, Lo L, Lu K. Insulin resistance in patients with chronic kidney disease.J Biomed Biotechnol. 2012;2012:1-12. doi: 10.1155/2012/691369.

24. Sarin SK, Choudhury A. Acute-on-chronic liver failure. Curr Gastroenterol Rep. 2016;18(12):61. doi: 10.1007/s11894-016 0535-8, PMID 27747458.

25. Langell JT, Mulvihill SJ. Gastrointestinal perforation and the acute abdomen. Med Clin North Am. 2008;92(3):599-625, viii. doi: 10.1016/j.mcna.2007.12.004, PMID 18387378.
26. Alhassan MB, Rabiu M, Agbabiaka IO. O. Interventions for Mooren's ulcer. Cochrane Database Syst Rev. 2014:1:CD006131. 10.1002/14651858.CD006131.pub3.

27. Osherov N, Gazit A, Gilon C, Levitzki A. Selective inhibition of the epidermal growth factor and HER2/neu receptors by tyrphostins. J Biol Chem.1993;268(15):11134-42. doi: 10.1016/S0021-9258(18)82102-0, PMID 8098709.

28. Anafi M, Gazit A, Zehavi A, Ben-Neriah Y, Levitzki A. Tyrphostin-induced inhibition of p210bcr-abl tyrosine kinase activity induces $\mathrm{K562}$ to differentiate. Blood. 1993;82(12):3524-9, PMID 7505115.

29. Shivani CP, Maheshwari DG. Development and validation of UV spectrometric and HPLC method for estimation of escitalopram oxalate and flupentixol dihydrochloride in combined dosage form. AJPTI. 2016;4:59-70.

30. Supriya T, Naresh D, Vijaya Kumar G, Haneer MA. Stability indicating RP-HPLC method development and validation for simultaneous estimation of escitalopram and flupentixol pure and marketed formulation. Asian J Pharm Res. 2018;8:4-10

31. International conference on the harmonization. ICH harmonized tripartite guideline. Validation of analytical procedures: text and methodology. Vol. Q2(R1); 2005.

32. Vijayakumari $\mathrm{M}$, Reddy $\mathrm{Ch}$ B. Stability indicating validated HPLC method for the determination of zanubrutinib in bulk and pharmaceutical dosage form. Asian J Pharm Clin Res. 2020;13:159-62.

33. Rajakumari R, Sreenivasa Rao S. Stress degradation studies and development of a validated RP-HPLC method for determination of tiagabine in presence of its degradation products. Int J Pharm Pharm Sci. 2016;8:230-6.

34. Charu Pandya P, Sadhana Rajput J. Development and validation of stability indicating method RP-HPLC method of acotiamide. Int J Pharm Pharm Sci. 2018;10:1-8.

35. Athavia BA, Dedania ZR, Dedania RR, Swamy SMV, Prajapati CB. Stability indicating HPLC method for determination of vilazodone hydrochloride. Int J Curr Pharm Sci;9(4). doi: 10.22159/ijcpr.2017v9i4.20975. 